Conclusion: In our trial of elderly rheumatoid arthritis patients, patients appeared to be mostly adherent according to conventional capsule counts. Results from adherence caps were highly discrepant with the capsule counts, with patterns suggesting patients did not use the bottle for daily dispensing, despite specific advice to do so.

References:

[1] El Alili M, Vrijens B, Demonceau J, Evers SM, Hiligsmann M. A scoping review of studies comparing the medication event monitoring system (MEMS) with alternative methods for measuring medication adherence. Br J Clin Pharmacol 2016;82:268-79.

Acknowledgments: The GLORIA project is funded by the European Union's Horizon 2020 research and innovation programme under the topic "Personalizing Health and Care", grant agreement No 634886.

Disclosure of Interests: Linda Hartman: None declared, Sabrina Paolino: None declared, Reinhard Bos: None declared, Daniela Opris-Belinski Speakers bureau: as declared, Marc R Kok Grant/research support from: BMS and Novartis, Consultant of: Novartis and Galapagos, Hanneke Griep-Wentink: None declared, Ruth Klaasen: None declared, Cornelia Allaart: None declared, George Bruyn: None declared, Hennie Raterman Grant/research support from: UCB, Consultant of: Abbvie, Amgen, Bristol-Myers Sqibb, Cellgene and Sanofi Genzyme, Marieke Voshaar Grant/research support from: part of phd research, Speakers bureau: conducting a workshop (Pfizer), Nuno Gomes: None declared, Rui Pinto: None declared, Thomas Klausch: None declared, WIllem Lems Grant/research support from: Pfizer, Consultant of: Lilly, Pfizer, Maarten Boers: None declared DOI: 10.1136/annrheumdis-2020-eular.3598

\section{FRI0582 $\quad$ GM-CSF PRODUCED BY CD4+ T CELLS AS A MARKER OF CLINICAL REMISSION IN PATIENTS WITH RHEUMATOID ARTHRITIS TREATED WITH TNF INHIBITORS}

B. Hernández-Breijo ${ }^{1}$, C. Plasencia ${ }^{1}$, C. García-Hoz ${ }^{2}$, C. Sobrino ${ }^{2}$, V. NavarroCompán ${ }^{1}$, A. Martínez-Feito ${ }^{1}$, I. Nieto-Gañán ${ }^{2}$, P. Lapuente-Suanzes ${ }^{2}$, J. Bachiller-Corral ${ }^{2}$, G. Bonilla ${ }^{1}$, C. Pijoan Moratalla ${ }^{2}$, G. Roy ${ }^{2}$, M. Vázquez Díaz ${ }^{2}$, A. Balsa ${ }^{1}$, L. M. Villar ${ }^{2}$, D. Pascual-Salcedo ${ }^{1}$, E. Rodríguez-Martín ${ }^{2}{ }^{1} /$ mmunoRheumatology Research Group, IdiPaz, La Paz University Hospital, Madrid, Spain; ${ }^{2}$ Immunology \& Rheumatology Departments. Ramón y Cajal University Hospital and IRYCIS, Madrid, Spain

Background: According to the EULAR recommendations, the therapeutic target in patients with RA should be remission (REM). However, no more than $50 \%$ of the patients treated with TNF inhibitors (TNFi) attains this outcome. Previous investigations suggested the peripheral blood mononuclear cells (PBMC) as markers associated with the TNFi treatment success ${ }^{1,2}$. Granulocyte-monocyte colony-stimulating factor (GM-CSF) plays a relevant role in the pathogenesis of rheumatoid arthritis (RA) because it promotes the macrophage differentiation, survival and activation ${ }^{3}$.

Objectives: To analyse the intracellular cytokine production by PBMC and its association with REM attainment after 6 months $(\mathrm{m})$ of TNFi treatment in patients with RA.

Methods: This was a prospective bi-center pilot study including 36 patients with RA. PBMC were isolated from patients at baseline and after $6 \mathrm{~m}$ of treatment with TNFi and cryopreserved until studied. Intracellular cytokine production by PBMC was stimulated in the presence of $2 \mu \mathrm{g} / \mathrm{mL}$ brefeldin as follow: monocytes were stimulated with $20 \mathrm{ng} / \mathrm{mL}$ LPS during $4 \mathrm{~h}$; and simultaneously lymphocytes were stimulated with $50 \mathrm{ng} / \mathrm{mL}$ phorbol 12-myristate 13-acetate (PMA) and $750 \mathrm{ng} / \mathrm{mL}$ ionomycin during $4 \mathrm{~h}$ at $37^{\circ} \mathrm{C}$. To identify IL-10-producing $\mathrm{B}$ cells, PBMC were pre-incubated with $3 \mu \mathrm{g} / \mathrm{mL}$ of $\mathrm{CpG}$ oligonucleotide during $20 \mathrm{~h}$ at $37^{\circ} \mathrm{C}$ prior to stimulation in presence of $2 \mu \mathrm{mol} / \mathrm{L}$ monensin. Intracellular cytokine production (TNFa, IL6, GM-CSF, IL10) by the different cell subsets (monocytes, CD4 ${ }^{+}$and $\mathrm{CD}^{+} \mathrm{T}$ cells, naïve and memory $\mathrm{B}$ cells) was analysed by flow-cytometry. Clinical activity at baseline and after $6 \mathrm{~m}$ was assessed by DAS28. REM was defined as DAS28 $\leq 2.6$ at $6 \mathrm{~m}$. The association between REM and the change in cytokine production $(\Delta, 6 \mathrm{~m}-0 \mathrm{~m})$ by each PBMC subset was analysed through univariable and multivariable logistic regression models.

Results: Seventy-eight percent of the patients were female. After $6 \mathrm{~m}$ of TNFi treatment, $47 \%$ patients attained REM. Univariable analyses was performed to investigate the association between REM and the baseline variables. Male sex (OR: 12.6; 95\% Cl: 1.35-117.57; $\mathrm{p}=0.03$ ) and having lower baseline DAS28 (OR: 0.4; $95 \% \mathrm{Cl}: 0.19-0.85 ; \mathrm{p}=0.02)$ were independently associated with attaining REM after $6 \mathrm{~m}$ of TNFi. In the multivariable analysis, only being male (OR: $19.7 ; 95 \%$ $\mathrm{Cl}$ : 1.4-273.9; $\mathrm{p}=0.03$ ) remained independently associated with REM after $6 \mathrm{~m}$ of treatment. Therefore, further analyses were adjusted by sex. Decreased production of GM-CSF by CD4 ${ }^{+}$T cells percentage was found after $6 \mathrm{~m}$ of TNFi treatment in REM patients (0m: $6.07 \%$; $6 \mathrm{~m}: 3.87 \% ; \mathrm{p}=0.007$ ) while no-REM patients did not show differences with the baseline (0m: 3.70\%; $6 \mathrm{~m}: 3.75 \% ; p=0.9)$. The decrease was significantly associated with attaining REM (OR: 0.56; $95 \% \mathrm{Cl}: 0.33-0.95$; :
0.03). No significant association was found between any other analysed intracellular cytokine produced by the different PBMC subsets and REM.

Conclusion: GM-CSF intracellular production by $\mathrm{CD} 4^{+} \mathrm{T}$ cells was significantly decreased by TNFi treatment only in patients who attained REM. Therefore, our results suggest that GM-CSF production by $\mathrm{CD} 4^{+} \mathrm{T}$ cells may be a useful marker of REM to TNFi in RA.

References:

[1] Sobrino C, et al. Ann Rheum Dis. 2019; 78 (S2): A1665.

[2] Hernández-Breijo B, et al. Ann Rheum Dis. 2019; 78 (S2): A711.

[3] Avci AB, et al. Clin Exp Rheumatol. 2016; 34 (S98), 39-44.

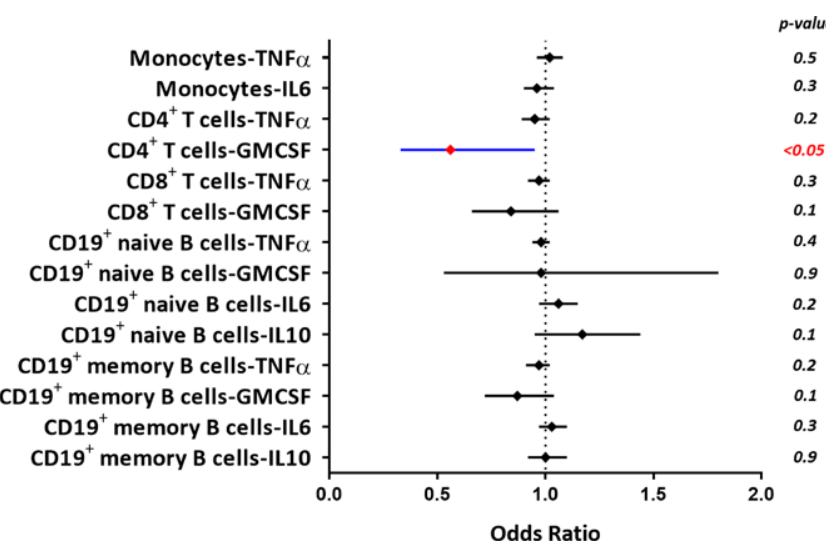

Figure. 1: Association between the change in intracellular cytokine production $(\Delta, 6 \mathrm{~m}-0 \mathrm{~m})$ by each PBMC subset and REM. Adjusted logistic regression analyses were performed for each cytokine.

Acknowledgments: ISCIII (PI16/00474; PI16/01092)

Disclosure of Interests: Borja Hernández-Breijo: None declared, Chamaida Plasencia: None declared, Carlota García-Hoz: None declared, Cristina Sobrino: None declared, Victoria Navarro-Compán Consultant of: Abbvie, Lilly, Novartis, Pfizer, UCB, Speakers bureau: AbbVie, MSD, Lilly, Novartis, Pfizer, UCB, ANA MARTÍNEZ-FEITO: None declared, Israel Nieto-Gañán: None declared, Paloma Lapuente-Suanzes: None declared, Javier Bachiller-Corral: None declared, Gemma Bonilla: None declared, Cristina Pijoan Moratalla: None declared, Garbiñe Roy: None declared, Mónica Vázquez Díaz: None declared, Alejandro Balsa Grant/research support from: BMS, Roche, Consultant of: AbbVie, Gilead, Lilly, Pfizer, UCB, Sanofi, Sandoz, Speakers bureau: AbbVie, Lilly, Sanofi, Novartis, Pfizer, UCB, Roche, Nor dic, Sandoz, Luisa María Villar: None declared, DORA PASCUAL-SALCEDO Grant research support from: Pfizer, Novartis \& Progenika, Speakers bureau: Pfizer, Merck, Novartis, Takeda, Menarini \& Grifols, Eulalia Rodríguez-Martín: None declared DOI: 10.1136/annrheumdis-2020-eular.1338

\section{FRI0583 \\ VALIDATION OF THE MODIFIED FATIGUE IMPACT SCALE IN DANISH PATIENTS WITH SYSTEMIC LUPUS ERYTHEMATOSUS}

C. I. Junker ${ }^{1}$, K. Duch ${ }^{2}$, L. Dreyer ${ }^{1}$, J. W. Gregersen ${ }^{3}$, S. Kristensen ${ }^{1} .{ }^{1}$ Aalborg University Hospital, Department of Rheumatology, Aalborg, Denmark; ${ }^{2}$ Aalborg University Hospital, Unit of Clinical Biostatistics, Aalborg, Denmark; ${ }^{3}$ Aalborg University Hospital, Department of Nephrology, Aalborg, Denmark

Background: Patients with systemic lupus erythematosus (SLE) experience significant fatigue, a debilitating symptom associated with reduced quality of life. A simple, reliable multidimensional method for assessing fatigue has not yet been validated for Danish patients with SLE.

Objectives: The primary objective was to study the internal consistency, test-retest reliability, and construct validity (convergent and discriminant validity) of the multidimensional Modified Fatigue Impact Scale (MFIS) in patients with SLE. The secondary objective was to investigate the contribution of disease activity and organ damage to fatigue.

Methods: Data from the "Bio and Genome Bank Study in Centre for SLE and Vasculitis" obtained through routine visits were used. Fatigue was assessed using the MFIS and Short Form 36 (SF36). Internal consistency of the MFIS was assessed with Cronbach's alpha (a). Test-retest reliability was evaluated using the intraclass correlation coefficient (ICC). Construct validity was studied using Spearman's rank correlation coefficient $(r)$ and Principal Component Analysis (PCA) between MFIS and SF36 vitality (VT-SF36) and mental health (MH-SF36) subscales. Association between MFIS and disease activity and organ damage was estimated with Spearman's rank correlation coefficient. 